Pesq. Vet. Bras. 34(Supl.1):74-78, dezembro 2014

DOI: $10.1590 / \mathrm{S} 0100-736 \mathrm{X} 2014001300014$

\title{
Serum dosage of CPK-MB in dogs with ST deviation by chemiluminescence ${ }^{1}$
}

\author{
André L.F. Santos ${ }^{2 *}$, Guilherme G. Pereira ${ }^{3}$, Mário M. Santos ${ }^{3}$, Vanda C.R. Gutierrez ${ }^{4}$, \\ Priscila C. Calyjur ${ }^{2}$ and Maria Helena M.A. Larsson ${ }^{3}$
}

\begin{abstract}
Santos A.L.F., Pereira G.G., Santos M.M., Gutierrez V.C.R., Calyjur P.C. \& Larsson M.H.M.A. 2014. Serum dosage of CPK-MB in dogs with ST deviation by chemiluminescence. Pesquisa Veterinária Brasileira 34(Supl.1):74-78. Setor de Patologia Veterinária, Faculdade de Medicina Veterinária e Zootecnia, Universidade de São Paulo, Av. Orlando Marques de Paiva 87, São Paulo, SP 05508-270, Brazil. E-mail: andrvet@usp.br

Although frequently in humans, hypoxic and ischemic heart diseases are poorly documented in dogs, with only few reports of acute myocardial infarction (AMI) in this species. Some electrocardiographic findings might suggest myocardium hypoxia/ischemia, like ST segment elevation or depression, but there are no studies showing whether deviations in ST segment are associated to myocardial injury and serum increase of creatine phosphokinase (CPK-MB). In order to investigate possible myocardial cells injury in poor perfusion conditions, 38 dogs were studied, 20 with normal electrocardiogram and 18 with ST segment elevation or depression, recorded in lead II, at a paper speed of $50 \mathrm{~mm} / \mathrm{sec}$ and $\mathrm{N}$ sensibility $(1 \mathrm{mV}=1 \mathrm{~cm})$. Serum measurement of creatine phosphokinase isoenzyme MB (CPK-MB) in normal dogs (group 1) determined control values (in $\mathrm{ng} / \mathrm{mL}$ ), which were compared to those obtained from dogs with deviation (group 2), which allowed confirmation or not of myocardial injury. CPK-MB mean values obtained from dogs in groups 1 and 2 were $0.540 \mathrm{ng} / \mathrm{ml}(\mathrm{SD} \pm 0.890) \mathrm{ng} / \mathrm{mL}$ and $0.440 \mathrm{ng} / \mathrm{mL}(\mathrm{SD} \pm 1.106)$, respectively. At a significance level of $5 \%$, the relation of CPK-MB with age, mass and total creatine phosphokinase (CPK-T) was not significant in groups 1 and 2. CPK-MB showed no difference, at $5 \%$ level, between groups 1 and 2 . In conclusion, it is possible to use the human chemiluminescent immunometric assay kit in canine species and that hypoxia/ischemia revealed by ST segment deviation does not mean significant myocardium injury.
\end{abstract}

INDEX TERMS: Creatinephosphokinase, CPK-MB, dogs, ST segment.

\begin{abstract}
RESUMO.- [A dosagem sérica de CPK-MB em cães com desvio ST por quimiluminescência.] Embora frequente em humanos, as doenças hipóxicas e isquêmicas do coração são pouco relatadas em cães, com poucos relatos de infarto agudo do miocárdio (IAM) nesta espécie. Alguns achados no eletrocardiograma podem sugerir hipóxia/isquemia miocárdica, como a elevação ou depressão do segmento ST,
\end{abstract}

\footnotetext{
${ }^{1}$ Received on September 5, 2014.

Accepted for publication on January 6, 2015.

${ }^{2}$ Centro de Pesquisas sobre o Genoma Humano e Células-Tronco, Rua do Matão 106, São Paulo, SP 05508-090. *Corresponding author: andrvet@ usp.br

${ }^{3}$ Departamento de Clínica Médica, Faculdade de Medicina Veterinária e Zootecnia, Universidade de São Paulo (USP), Av. Orlando Marques de Paiva 87, São Paulo, SP 05508-270, Brazil.

${ }^{4}$ Hospital Universitário, USP, Av. Orlando Marques de Paiva 87, São Paulo, SP 05508-000.
}

mas não há estudos que mostram se os desvios do segmento ST estão associados a lesões miocárdicas e aumento sérico da creatinafosfoquinase (CPK-MB). A fim de investigar possíveis lesões nas células miocárdicas em condições de má perfusão, 38 cães foram estudados, 20 com eletrocardiograma normal e 18 com elevação ou depressão do segmento ST, registrados em papel, na derivação II, velocidade de $50 \mathrm{~mm} / \mathrm{s}$ e sensibilidade $\mathrm{N}(1 \mathrm{mV}=1 \mathrm{~cm})$. A mensuração da creatinafosfoquinase isoenzima MB (CPK-MB) em cães normais (grupo 1) determinou os valores controle (em ng/ $\mathrm{ml}$ ), que foram comparados com os obtidos a partir de cães com desvio (grupo 2), permitindo a confirmação ou não da lesão miocárdica. Os valores médios de CPK-MB obtidos de cães nos grupos 1 e 2 foram $0,540 \mathrm{ng} / \mathrm{ml}(\mathrm{DP} \pm 0,890)$ e $0,440 \mathrm{ng} / \mathrm{ml}$ (DP \pm 1.106 ), respectivamente. A um nível de significância de $5 \%$, a relação de CPK-MB com a idade, massa e creatinofosfoquinase total (CPK-T) não foi significativa 
nos grupos 1 e 2. Não houve diferenças na CPK-MB, ao nível de $5 \%$, entre os grupos 1 e 2 . Conclui-se que é possível utilizar o kit de ensaio imunométrico por quimioluminescência humano na espécie canina e que a hipoxia/isquemia revelada pelos desvios do segmento ST, não significa lesão miocárdica.

TERMOS DE INFDEXAÇÃO: Creatinafosfoquinase, CPK-MB, cães, segmento ST.

\section{INTRODUCTION}

Acute myocardial infarction is a common affection in humans, having as a typical symptom the "chest pain" irradiating to the back and arms. Individuals with these symptoms are monitored by electrocardiogram and by dosing myocardial hypoxia-ischemia markers (Bonow et al. 2009, Tharwat 2013). Myocardial hypoxia is the insufficient cardiac muscle oxygenation (Robbins et al. 2001), in spite of the adequate perfusion (Bonow et al. 2009), while ischemia is the oxygen deprivation followed by inadequate metabolites removal.

During hypoxia, enzymes are liberated in the blood circulation (Loegering \& Critz 1971) and, in case of hypoxia/ myocardial infarction, creatine phosphokinase (CPK) catalyses the reversible reaction: creatine + ATP > phosphocreatine + ADP, named Lohman Reaction (Aktas et al. 1993, Bottomley \& Weiss 2001).

CPK is a dimeric molecule of 381 amino acids that consists of two subunits, ( $M$ and $B$, which have the same weight but are immunologically distinct and synthesized by two different genes) and presents 282 cysteine residues that are necessary for its catalytic activity. There are three isoenzymes: CPK-MM, present in striated muscle; CPK-BB, present predominantly in the brain and digestive system and CPK-MB, present in the cardiac tissue, kidneys, intestines and lungs (Aktas et al. 1993).

CPK synthesis control is not well understood. Studies show that, in dogs myocardium, short term anoxia causes an increase in the concentration of the mRNA for the B subunit synthesis, resulting in an increase of $35 \%$ to $100 \%$ of the CPK-MB serum activity, therefore it is used for the diagnosis of experimentally induced acute myocardial infarction in dogs (Aktas et al. 1993).

In dogs, the increase in CPK-MB serum activity occurs in myocardial involvement following parvovirosis, heart-worms, endocarditis, hypertrophic cardiomyopathy (Aktas et al. 1993), racing (Tharwat 2013) and the opposite is observed in dilated cardiomyopathy in Dobermans (O'Brien 1997). Although being considered as gold standard in myocardial injury diagnosis, it cannot be ignored that CPK is present in other organs, diminishing its specificity (Ramos\& Magalhães 2002).

CPK variant isoenzymes, named macro-CPK types I and II, are the common reason of false positives in CPK-MB serum activity measures. Macro-CPK type I is frequent in elderly women, while macro-CPK type II is frequent in hepatic cirrhosis and metastatic disease in human patients (Camarozano \& Henriques 1996, Ricchiuti et al. 1998, Ramos \& Magalhães, 2002).
In human infarction patients, CPK-MB levels increase in 4 to 12 hours from the start of "angor pectoris" and serum levels return to base values in 48 to 72 hours (Ramos \& Magalhães 2002). According to Ricchiuti et al. (1998), serum CPK-MB release in dogs with experimental coronary occlusion is similar to this enzyme release during acute myocardial infarction in humans. Activity or weight determination of CPK-MB can be conducted in serum or heparinized plasma (Aktas et al. 1994, Tharwat 2013), although hemolisys or hyperbilirubinemia may result in false serum CK-MB increases, what does not happen in lipemic serum (Aktas et al. 1993).

Artherosclerosis is rare in dogs and when it occurs, it is associated to uncontrolled hypothyroidism, but hypoxia-ischemia, with consequent infarction is common due to coronary embolism, - infectious endocarditis, particularly of the aortic valve - septicemia and pulmonary neoplasia (Thomas 1987). Dogs presenting gastric dilatation-volvulus syndrome frequently develop ventricular arrhythmia extrasystolic and ventricular tachycardia - that may cause focal ischemia and myocardial necrosis, and the same fact occurs in acute pancreatitis (Herndon et al. 2002, Burgener et al. 2006).

ST segment increase/decrease are common in Veterinary Cardiology and these electrocardiographic findings agree with myocardial hypoxia and ischemia respectively. However, there are very few papers in veterinary medicine that associate this electrocardiographic alteration to myocardial injury and serum CPK-MB levels increase.

Electrolitic disturbances, especially those related to potassium $\left(\mathrm{K}^{+}\right)$, can cause alterations in the ST segment morphology in the absence of myocardial hypoxia/ischemia, hence the need to dose serum $\mathrm{K}^{+}$when ST segment deviations are present (Tilley 1992). Hypopotassemia occurs when the serum potassium level is under $3,0 \mathrm{mEq} / \mathrm{L}$, causing an increase in the intracellular/extracellular $\mathrm{K}^{+}$ relation, making the myocardium less excitable. The causes are chronic renal insufficiency, excessive administration of mineralocorticoids, emesis, severe diarrhea and prolonged administration of loop diuretics in high doses (Tilley \& Junior 2003). In hyperpotassemia, the serum $\mathrm{K}^{+}$ concentration is over $6.5 \mathrm{mEq} / \mathrm{L}$ and there is, consequently, a decrease in the intracellular/extracellular $\mathrm{K}^{+}$relation and myocardial hyper excitability, having as causes acute renal insufficiency, vesicle rupture, urethral obstruction, muscle trauma, digitalis intoxication, high doses of potassium-sparing diuretics, among others (Tilley \& Junior, 2003).

The objectives of this study are to investigate possible myocardial injury and increase in serum CPK-MB in dogs presenting ST segment deviations.

\section{MATERIALS AND METHODS}

We used 38 dogs, males and females, known breeds or not, variable body weight and ages, distributed in two groups: group 1 consisted of 20 healthy dogs, with normal electrocardiograms and group 2 consisted of 18 dogs presenting uneven ST segments.

The dogs were provided by the Cardiology Services of the University Veterinary Hospital and their participation was approved 
by the College of Veterinary Medicine and Zootechnics of USP Bioethics Commission, protocol no 238/2002. Dogs presenting neoplasias, gastroenteritis, dermopathies and that frequented coastal areas - because of the risk of contracting Dirofilaria immitis - were not included in the study. Physical examination constituted in determining the cardiac and respiratory frequencies, measuring the rectal temperature, inspection of the oral, ocular and penile-vaginal mucous membranes, abdominal and linfonodes palpation and cardio respiratory auscultation.

The radiographic examinations were made in the CGR radiodiagnostic equipment, model Chenonceaux, of $600 \mathrm{~mA}$ and $130 \mathrm{Kv}$, with radiologic table with grid and Potter-Bucky recipromatic system type Par Speed, rotating anode X-ray tube. The films were developed in the automatic processor RP-OMAT Processor Kodak. The radiographic examination was made in three projections: right latero-lateral, left latero-lateral and dorsoventral.

Electrocardiograms were made in Ecafix ECG machine, model ECG-6 or Schiller model AT-1v, with the animals positioned in right lateral decubitus on isolating surface. Bipolar derivations DI, DII and DIII were taken and the augmented unipolar aVR, aVL and aVF, besides the pre cordial derivation CV5RL, CV6LL, CV6LU and V10, according to Tilley \& Junior (2003).

Ecocardiograms were made in ultrasonography machine Hitachi, model EUB 515-A, with 5MHz micro convex transducer. A Sony printer, model UP 890-CE was used. The following parameters were measured and calculated in M mode, according to the specifications and values Boon (2011): dimension of the left ventricle cavity in the end of systole (DSVEs); thickness of the left ventricular free wall in diastole (Epd), thickness of the interventricular septum in diastole (ESd); shortening fraction (FE), calculated by the formula (DVEd-DVEs)x100/DVEd; aortic root (Ao), diameter of the left atrium (AE) and relation between Ao and $\mathrm{AE}$.

Blood samples were collected by puncturing the radial, saphena or jugular veins - either right or left - using disposable needles and syringes. We used tubes containing EDTA-K2 with anticoagulant to perform the hemogram and tubes without anticoagulant for the serum biochemistry and CPK-MB tests. After collection, the blood was centrifuged at $1500 \mathrm{~g}$ for 10 minutes. Blood serum for dosing CPK-MB (mass) and $\mathrm{K}^{+}$was kept at $-20^{\circ} \mathrm{C}$ for 24 hours. Hemogram, renal and hepatic profiles and serum $\mathrm{K}^{+}$ determination were conducted at the Clinical Laboratory of the Veterinary Hospital of FMVZ-USP, while CPK-MB measure was conducted at the University Hospital Clinical Laboratory-HU-USP. Total count of erithrocytes and leukocytes and hemoglobin determination were performed using the automated system Serono, model System 9020AX. The hematocrit was determined by the microhematocrit technique in a Celm centrifuge, model $\mathrm{MH}$ and the differential count of leukocytes was performed under Carl Zeiss Jenamed optical microscope in in natura blood smears stained by Rosenfield.

The evaluation of the renal and hepatic profiles and total CPK (CPK-T) was conducted by Technicon-Bayer automated biochemical analyser, model RA-100. The renal profile was evaluated by serum urea levels - urease colorimetric assay - and creatinine levels, by the kinetic method. The hepatic profile was evaluated by the determination of serum alkaline phosphatase (kinetic colorimetric assay), aspartate and alanine aminotransferase (kinetic assay in ultraviolet), total protein (biuret assay) and albumin (bromocresol green assay). CPK-T was dosed by chemical chain reactions involving hexokinase and glucose-6-phosphate dehydrogenase as from the speed of formation of NADPH, measured at $340 \mathrm{~nm}$.

Serum potassium dosage was performed by the ion-selective electrode assay, using the OMNI-4 analyser.

CPK-MB was calculated by chemiluminescence according to the following procedure: 1) test unit: anti-ligand (Avidin) coated pearl. Patient serum is added (50ul) and incubated at $37^{\circ} \mathrm{C}$ for 30 minutes under intermittent agitation; 2) $6.5 \mathrm{ml}$ of reagent is added. It constitutes of two types of mouse monoclonal antibodies: biotin labeled anti-CPK-MB which will bind to the avidin in the pearl and a buffered anti-CPK-BB labeled with alkaline phosphatase; 3 ) serum CPK-MB and CPK-BB bind to the respective antibodies; 4) chemiluminescent substrate (ester phosphate adamantly dioxetane) is added and incubated for 10 minutes, followed by reading in luminometer ( $\mathrm{CPK}-\mathrm{BB}$ is measured and $\mathrm{CPK}-\mathrm{MB}$ is indirectly measured through mathematical equations); 5) some assay characteristics: a) calibration: up to $500 \mathrm{ng} / \mathrm{mL}$; b) analytical sensitivity: $0.42 \mathrm{ng} / \mathrm{mL}$; specificity: CPK-MB specific antibody with low cross reaction with other isoenzymes; c) bilirubin causes depression in the measured values; d) hemolysis: eritrocytes presence in the concentration of up to $30 \mathrm{ug} / \mathrm{mL}$ does not alter the assay precision.

\section{RESULTS}

The animals in group 1 presented hemogram, potassium, renal and hepatic profiles and thoracic radiological exams inside the normal standards (Tilley \& Junior 2003). The obtained results of CPK-T were within the normal reference values, between 20 to $235 \mathrm{U} / \mathrm{L}$.

Groups 1 and 2 presented disparities concerning age and body weight. The dogs in group 1 were younger - 19 dogs less than 6 years old. In group 2, the majority of the dogs were older -15 animals with more than 7 years. The dogs in group 1 presented more body mass and more homogeneously distributed in comparison to group 2 . In relation to CPK-MB, group 1 dogs presented a mean of $0,540 \mathrm{ng} /$ $\mathrm{mL}$ and standard deviation of $0.890 \mathrm{ng} / \mathrm{mL}$ and group 2 presented mean of $0.440 \mathrm{ng} / \mathrm{mL}$ and standard deviation of $1.106 \mathrm{ng} / \mathrm{mL}$. Fisher exact test, in 5\% significance level, did not detect any association between the groups and the serum CK-MB (Table 1 and 2).

Table1. Identification and serum CPK-MB and CPK-T in normal dogs (group 1)

\begin{tabular}{ccccccc}
\hline Identification & $\begin{array}{c}\text { Racial } \\
\text { definition }\end{array}$ & Sex & $\begin{array}{c}\text { Age } \\
\text { (years) }\end{array}$ & $\begin{array}{c}\text { Mass } \\
\text { (g) }\end{array}$ & $\begin{array}{c}\text { CPK-MB } \\
(\mathrm{ng} / \mathrm{mL})\end{array}$ & $\begin{array}{c}\text { CPK-T } \\
(\mathrm{U} / \mathrm{mL})\end{array}$ \\
\hline 1 & WRD & $\mathrm{F}$ & 2 & 14,70 & 0,85 & 83,74 \\
2 & WRD & $\mathrm{M}$ & 2 & 6,20 & 0,86 & 142,85 \\
3 & WRD & $\mathrm{F}$ & 3 & 20,40 & 0,39 & 169,38 \\
4 & WRD & $\mathrm{F}$ & 2 & 10,30 & $<0,05$ & 88,90 \\
5 & WRD & $\mathrm{M}$ & 6 & 21,30 & 0,76 & 471,66 \\
6 & Poodle Toy & $\mathrm{F}$ & 6 & 7,00 & 1,20 & 190,07 \\
7 & Poodle Toy & $\mathrm{F}$ & 6 & 4,20 & 1,90 & 312,91 \\
8 & WRD & $\mathrm{M}$ & 2 & 10,20 & 0,04 & 88,68 \\
9 & Poodle Toy & $\mathrm{M}$ & 6 & 8,20 & 3,60 & 203,50 \\
10 & Labrador Retriever & $\mathrm{F}$ & 3 & 31,80 & $<0,05$ & 60,21 \\
11 & Belgian Sheperd & $\mathrm{M}$ & 7 & 24,20 & $<0,05$ & 159,55 \\
12 & Teckel & $\mathrm{M}$ & 2 & 12,40 & 0,25 & 88,01 \\
13 & WRD & $\mathrm{F}$ & 3 & 24,70 & $<0,05$ & 72,68 \\
14 & WRD & $\mathrm{M}$ & 5 & 19,00 & 0,75 & 125,95 \\
15 & WRD & $\mathrm{F}$ & 2 & 21,80 & 0,16 & 68,79 \\
16 & WRD & $\mathrm{M}$ & 3 & 16,60 & $<0,05$ & 140,82 \\
17 & WRD & $\mathrm{M}$ & 3 & 19,00 & $<0,05$ & 7,99 \\
18 & WRD & $\mathrm{M}$ & 2 & 12,00 & $<0,05$ & 113,81 \\
19 & WRD & $\mathrm{M}$ & 2 & 17,40 & $<0,05$ & 164,91 \\
20 & WRD & $\mathrm{M}$ & 3 & 15,40 & $<0,05$ & 101,92
\end{tabular}

$\overline{\mathrm{WRD}}=$ without racial definition; $\mathrm{M}$ : male; F: female. $<0,05=$ almost undetectable. 
Table 2. Identification and serum CPK-MB and CPK-T in dogs with ST-segment deviations (group 2)

\begin{tabular}{ccccccc}
\hline Identification & $\begin{array}{c}\text { Racial } \\
\text { definition }\end{array}$ & Sex & $\begin{array}{c}\text { Age } \\
\text { (years) }\end{array}$ & $\begin{array}{c}\text { Mass } \\
\text { (g) }\end{array}$ & $\begin{array}{c}\text { CPK-MB } \\
(\mathrm{ng} / \mathrm{mL})\end{array}$ & $\begin{array}{c}\text { CPK-T } \\
(\mathrm{U} / \mathrm{mL})\end{array}$ \\
\hline 1 & Poodle & $\mathrm{M}$ & 10 & 7,70 & $<0,05$ & 51,46 \\
2 & WRD & $\mathrm{M}$ & 16 & 5,90 & $<0,05$ & 82,86 \\
3 & Cocker Spaniel & $\mathrm{F}$ & 3 & 10,00 & 0,42 & 10,31 \\
4 & Poodle Toy & $\mathrm{M}$ & 8 & 2,80 & $<0,05$ & 178,09 \\
5 & Dobermann & $\mathrm{M}$ & 9 & 26,00 & 0,33 & 187,34 \\
6 & Poodle & $\mathrm{M}$ & 12 & 15,20 & 0,02 & 10,37 \\
7 & Yorkshire & $\mathrm{F}$ & 9 & 3,20 & $<0,05$ & 67,03 \\
8 & Poodle & $\mathrm{M}$ & 8 & 10,70 & $<0,05$ & 187,65 \\
9 & Brazilian Terrier & $\mathrm{F}$ & 11 & 15,30 & 0,06 & 62,86 \\
10 & Poodle & $\mathrm{M}$ & 14 & 4,80 & 0,64 & 295,38 \\
11 & Teckel & $\mathrm{M}$ & 11 & 5,60 & 0,65 & 79,53 \\
12 & Poodle Toy & $\mathrm{M}$ & 11 & 2,60 & 4,70 & 463,98 \\
13 & Poodle Toy & $\mathrm{F}$ & 1 & 2,40 & 1,00 & 115,63 \\
14 & Brazilian Terrier & $\mathrm{M}$ & 4 & 11,40 & $<0,05$ & 43,79 \\
15 & Cocker Spaniel & $\mathrm{F}$ & 11 & 14,00 & 0,03 & 150,50 \\
16 & WRD & $\mathrm{F}$ & 12 & 10,80 & $<0,05$ & 58,17 \\
17 & Teckel & $\mathrm{M}$ & 9 & 11,20 & $<0,05$ & 221,54 \\
18 & Cocker Spaniel & $\mathrm{F}$ & 7 & 12,00 & $<0,05$ & 38,96
\end{tabular}

$\overline{\mathrm{WRD}}=$ without racial definition; M: male; F: female. $<0,05=$ almost undetectable.

\section{DISCUSSION}

Veterinary literature still lacks studies that contemplate cardiac markers, however, in recent years papers were published measuring CPK-MB and troponins T and I in healthy dogs and in some specific cases, like myocardiopathies, arrhythmia, dyspnea, gastric dilatation-volvulus syndrome and after prolonged exercise (Fonfara et al. 2010, Tharwat et al. 2013).

Regarding CPK-MB, group 1 dogs presented mean of $0.54 \mathrm{ng} / \mathrm{mL}$ and standard deviation of $0.89 \mathrm{ng} / \mathrm{mL}$ and group 2 presented mean of $0.44 \mathrm{ng} / \mathrm{mL}$ and standard deviation of $1.106 \mathrm{ng} / \mathrm{mL}$. Tharwat et al. (2013) dosed CPK-MB in Greyhounds before, 2 hours later and 24 hours after a $7 \mathrm{~km}$ race and got a mean of $0.35 \mathrm{ng} / \mathrm{mL}$ by Elisa assay. Animals in group 2 presented a more homogeneous body weight distribution, which did not occur in group 1 . That can be explained by the predominance of Poodles (seven animals) and Cocker Spaniels (three animais), that together constituted $55 \%$ of the sample (table 2). Regarding CPK-MB, both groups showed high frequence of null values that weresimilar to those found by Tharwat et al. (2013), consisting of values varying between 0.1 and $0.2 \mathrm{mg} / \mathrm{mL}$, considered very low.

There were evidences of the association between CPK-MB and body weight in both groups, since the lower the body weight, the higher the serum CPK-MB concentration. Small dogs present higher cardiac frequencies and are generally more susceptible to stress, and consequently to phisiological miocardial hipoxya durind systole (Bonow et al. 1991).

Although higher levels of CPK-MB were expected in group 2, statistical tests did not reveal significative differences in levels in both groups. There are few studies in dogs associating CPK-MB levels with ST segment deviations. One of the stimuli for the formation of collateral vasculature deriving from the coronary trunk is chronic hipoxya/ ischemia (Braunwald \& Sobel 1991). With this information, it could be considered that in group 2 , deficient myocardial oxygenation would be a stimulus to the formation of enough collateral vasculature which could keep myocyte integrity or minimize the injuries, but that would not avoid the repolarization disturbance. CPK-MB is not a good marker for small injuries, once its serum levels increase slowly, what can explain so many null values (Ramos \&Magalhães 2002, Tharwat 2013).

\section{CONCLUSIONS}

The human chemiluminescent immunometric assay kit for serum CK-MB measure, can be used in dogs to monitor possible myocardial damage, in experimental or clinical conditions.

The mean CPK-MB values obtained in healthy animals cannot be considered referential because of the sample size, but they confirm the results found by Tharwat et al. (2013). If there is no difference among the animals, it is suggested that CPK-MB is not sensitive in the detection of myocardial lesions, or that these lesions are insignificant.

Study limitations.- As this is a clinic study and thus depends on the animals owners willingness and because said animals are healthy, it was not possible to perform the electrocardiographic monitoring and establish the CPK-MB curve for, at least, 6 hours.

\section{REFERÊNCIAS}

Aktas M., August D., Lefebure H.P., Toutain P.L. \& Braun J.P. 1993. Creatine kinase in the dog: a review. Vet. Res. Commun. 17:353-369.

Aktas M., August D., Concordet D., Vinclair P., Lefebvre H., Tountain P.L. \& Braun J.P. 1994. Creatine kinase in dog plasma: preanalytical factors of variation, reference values and diagnostic significance. Res. Vet. Sci. 56:30-36.

Bonow R.O., Libby P. \& Zipes D.P. 2009. Braunwald - Tratado de Doenças Cardiovasculares. 8a ed. Guanabara Koogan, Rio de Janeiro. 4864p.

Boon J.A. 2011. Veterinary Ecocardiography. $2^{\text {a }}$ ed. Wiley Blackwell, West Sussex. 632p.

Bottomley P.A. \& Weiss R.G. 2001. Noninvasive localized MR quantification of creatine kinase metabolities in normal and infracted canine myocardium. Radiology 219:411-418.

Camarozano A.C.A \& Henriques L.M.G. 1996. Uma macromolécula capaz de alterar o resultado do CK-MB e induzir ao erro diagnóstico de infarto do miocárdio. Arqs Bras. Cardiol. 66:1-9.

DPC 2002. CK-MB. DPC, São Paulo. 25p.

Loegering D.J. \& Critz J.B. 1971. Effect of hypoxia and muscukar activity on plasma enzyme levels in dogs. Am. J. Physiol. 220:100-103.

O'brien P.J. 1997. Deficiencies of myocardial troponin-T and creatine kinase MB isoenzyme in dogs with idiopathic dilated cardiomyopathy. Am. J. Vet. Res. 58:11-16.

Ramos R.F. \& Magalhães H.M. 2000. Infarto agudo do miocárdio: novos métodos de diagnóstico e prognóstico, p.147-151. In: Timerman A. \& César L.A.M. (Eds), Manual de Cardiologia (SOCESP). Atheneu, São Paulo, SP.

Ricchiuti V., Sharkey S.W., Murakami M.M., Voss E.M. \& Apple F.S. 1998. Cardiac troponin I and T alteration in dog hearts with myocardial infarction. Am. J. Clin. Pathol. 110:241-247.

Rishniw M., Barr S.C., Simpson K.W., Winand N.J. \& Wootton J.A.M. 2004. Cloning and sequencing of the canine and feline cardiac troponin I genes. Am. J. Vet. Res. 65:53-58.

Robbins S.L., Kumar V. \& Cotran R.S. 2001. Patologia Estrutural e Funcional. 6a ed. Guanabara Koogan, Rio de Janeiro. 780p. 
Schobber K., Kirbach B., Cornand C. \& Oechtering G. 2002. Diagnostische und differenzialdiagnostische Wertigkeit zirkulierender kardialer Troponine bei Hund und Katze. Tierärztl. Praxis 30:327-331.

Tharwat M., Al-Sobayil F. \& Buczinski S. 2013. Influence of racing on the serum concentrations of the cardiac biomarkers troponin I and creatine kinase myocardial band (CK-MB) in racing greyhounds. Vet. J. 197:900902.
Thomas W.P. 1987. Cardiology, p.117-156. In: Bonagura J.D. (Ed.), Myocardial Disease of the Dog. Churchill Livingstone, New York.

Tilley L.P. \& Junior F.W.K.S. 2003. Consulta Veterinária em 5 minutos. $2^{\underline{a}}$ ed. Manole, São Paulo. 1423p.

Tilley P.L. 1992. Essentials of canine and feline eletrocardiography: interpretation and treatment, p.84-87. In: Tilley P.L. (Ed.), ST Segment Abnormalities. Lea and Febiger, Philadelphia. 